\title{
Determinants of mRNA Stability in Dictyostelium discoideum Amoebae: Differences in Poly(A) Tail Length, Ribosome Loading, and mRNA Size Cannot Account for the Heterogeneity of mRNA Decay Rates
}

\author{
ROBERT A. SHAPIRO,† DAVID HERRICK, RICHARD E. MANROW, \\ AND ALLAN JACOBSON* \\ Department of Molecular Genetics and Microbiology, University of Massachusetts Medical School, \\ Worcester, Massachusetts 01655
}

Received 22 October 1987/Accepted 25 January 1988

\begin{abstract}
As an approach to understanding the structures and mechanisms which determine mRNA decay rates, we have cloned and begun to characterize cDNAs which encode mRNAs representative of the stability extremes in the poly $(\mathrm{A})^{+}$RNA population of Dictyostelium discoideum amoebae. The cDNA clones were identified in a screening procedure which was based on the occurrence of poly(A) shortening during mRNA aging. mRNA half-lives were determined by hybridization of poly $(\mathrm{A})^{+} \mathrm{RNA}$, isolated from cells labeled in $\mathrm{a}^{{ }^{32} \mathrm{PO}_{4}}$ pulse-chase, to dots of excess cloned DNA. Individual mRNAs decayed with unique first-order decay rates ranging from 0.9 to $9.6 \mathrm{~h}$, indicating that the complex decay kinetics of total poly $(A)^{+}$RNA in $D$. discoideum amoebae reflect the sum of the decay rates of individual mRNAs. Using specific probes derived from these cDNA clones, we have compared the sizes, extents of ribosome loading, and poly(A) tail lengths of stable, moderately stable, and unstable mRNAs. We found (i) no correlation between mRNA size and decay rate; (ii) no significant difference in the number of ribosomes per unit length of stable versus unstable mRNAs, and (iii) a general inverse relationship between mRNA decay rates and poly(A) tail lengths. Collectively, these observations indicate that mRNA decay in $D$. discoideum amoebae cannot be explained in terms of random nucleolytic events. The possibility that specific $3^{\prime}$-structural determinants can confer mRNA instability is suggested by a comparison of the labeling and turnover kinetics of different actin mRNAs. A correlation was observed between the steady-state percentage of a given mRNA found in polysomes and its degree of instability; i.e., unstable mRNAs were more efficiently recruited into polysomes than stable $m R N A s$. Since stable $m R N A s$ are, on average, "older" than unstable mRNAs, this correlation may reflect a translational role for mRNA modifications that change in a time-dependent manner. Our previous studies have demonstrated both a time-dependent shortening and a possible translational role for the $3^{\prime}$ poly(A) tracts of mRNA. We suggest, therefore, that the observed differences in the translational efficiency of stable and unstable mRNAs may, in part, be attributable to differences in steady-state poly(A) tail lengths.
\end{abstract}

We have previously demonstrated that the mRNA population in vegetatively growing amoebae of the cellular slime mold Dictyostelium discoideum decays with complex kinetics, consisting of at least two major components: a rapidly decaying component with a half-life of approximately 50 min, and a long-lived component with a half-life of approximately $10 \mathrm{~h}(14,58)$. Similar complex kinetics have been observed for the decay of poly $(A)^{+}$RNA in a variety of other eucaryotic cells $(5,25,39,57,77,78,81)$. It is likely that these complex decay kinetics reflect the sum of the decay rates of individual mRNAs (e.g., in $D$. discoideum, the most stable mRNAs have half-lives of approximately 10 $h$ and the least stable $m R N A s$ have half-lives which are approximately 10 -fold shorter). It has been suggested that such large differences in the stability of individual mRNAs could be accounted for by differences in their respective sizes $(39,52,58,63,78,81)$, poly(A) tail lengths $(8,28,56$,

\footnotetext{
* Corresponding author.

† Present address: Department of Pharmacology, University of Washington, Seattle, WA 98195.

¥ Present address: National Cancer Institute, Bethesda, MD 20892.
}

91), ribosome loading $(1,26,33,41,45)$, or $5^{\prime}-$ and $3^{\prime}$ untranslated (UT) sequences $(42,53,64,69,74,76,89)$. To test the validity of these hypotheses, we have identified cloned cDNAs which encode mRNAs that are representative of the stability extremes in $D$. discoideum and have initiated a characterization of the properties of the respective mRNAs.

To assess the relative stabilities of different mRNAs, we measured mRNA half-lives by hybridization of RNA labeled in a ${ }^{32} \mathrm{PO}_{4}$ pulse-chase to dots of excess cloned cDNA. With this assay, individual mRNAs were found to have distinct first-order decay rates which spanned the same spectrum of half-lives observed for the decay of total poly $(A)^{+}$RNA. Having identified stable, moderately stable, and unstable mRNAs, we then compared their sizes, extents of ribosome loading, and poly(A) tail lengths to ascertain whether any specific properties could be correlated with mRNA stability or instability.

\section{MATERIALS AND METHODS}

Plasmids. The cDNA clones whose construction is described below are designated p1, p2, p3, etc. In addition, the following plasmids were used in this study. (i) pcDd actin B1 
contains a cDNA insert, encoding a Dictyostelium discoideum actin mRNA, cloned in the PstI site of pBR322 (4). (ii) Actin 6 contains a genomic DNA insert encoding a Dictyostelium actin mRNA (67) cloned in pMB9. (iii) PST3 contains a 2.2-kilobase-pair PstI fragment of Dictyostelium genomic DNA cloned in pUC9 (R. A. Shapiro, Ph.D. thesis, Worcester Polytechnic Institute, Worcester, Mass., 1985). This genomic DNA fragment is complementary to the cDNA insert of pcDdI-42, a cDNA clone encoding a developmentally regulated Dictyostelium transcript (70). (iv) PSK80 contains a cDNA insert cloned in the PstI site of pBR322 which encodes an mRNA which preferentially accumulates in prestalk cells. The clone was isolated by $D$. Ratner from a cDNA library described by Mehdy et al. (49) and was originally designated $18 \mathrm{G} 1$. (v) NS28 contains a cDNA insert cloned in the PstI site of pBR322 which encodes a mRNA present throughout most of the Dictyostelium life cycle and which preferentially accumulates in prespore cells. The clone was isolated by $D$. Ratner from a cDNA library described by Mehdy et al. (49) and was originally designated 7E3. Plasmids pcDd actin B1, actin 6, and pcDdI-42 were the generous gifts of R. Firtel and plasmids PSK80 and NS28 were the generous gifts of $D$. Ratner.

Cloning of cDNAs which encode stable or unstable mRNAs. The method used (Shapiro, Ph.D. thesis) to isolate the cDNA clones employed in these experiments took advantage of the observation that newly synthesized mRNA in $D$. discoideum has a long $3^{\prime}$ poly(A) tract that shortens as the mRNA ages (58-61). This implies that an unstable mRNA will undergo significant degradation before its $3^{\prime}$ poly(A) tract shortens and that there should be a reduction in the relative concentration of unstable mRNAs in mRNA fractions of decreasing poly(A) size. Therefore, a cDNA library was constructed from mRNA with long poly(A) tails $(\sim 85$ adenylate residues), and the library was screened by hybridization (24) to ${ }^{32} \mathrm{P}$-labeled cDNA reverse transcribed from mRNA with long poly(A) and with short poly(A) ( $\sim 35$ adenylate residues). cDNA cloning in the PstI site of pUC9 (85) followed conventional procedures $(10,44,87)$. mRNA containing long poly(A) was thermally eluted from poly(U)Sepharose (59) between 45 and $55^{\circ} \mathrm{C}$, and mRNA containing short poly $(A)$ was thermally eluted from poly(U)-Sepharose between 25 and $35^{\circ} \mathrm{C}$. Colonies exhibiting differential hybridization to the long poly $(A)$ probe were chosen as candidates for cDNA clones representing unstable mRNAs, while colonies exhibiting differential hybridization to the short poly(A) probe were chosen as candidates for cDNA clones representing stable mRNAs (Shapiro, Ph.D. thesis). Selected cDNA clones were subsequently screened by northern (RNA) and Southern blot analysis to identify (and eliminate) those clones that encoded the same mRNA, represented multiple copy genes, or might possess repetitive sequences analogous to those found in other Dictyostelium mRNAs $(34,91)$. The final set of cloned cDNA sequences included two which potentially encoded unstable mRNAs and eight which potentially encoded stable mRNAs (Table 1). The mRNAs encoded by the set of cloned DNAs were all found in polysomes (see below) and ranged in size from 400 to 1,500 nucleotides (Table 1 ).

Cell culture and RNA extraction. Cells of $D$. discoideum AX3 were grown axenically in MES-HL5 medium at $22^{\circ} \mathrm{C}$ (59). Methods for extraction of whole-cell RNA were as described previously $(30,59)$.

Phosphate pulse-chase. A 50-ml portion of AX3 cells at $4 \times$ $10^{6}$ per $\mathrm{ml}$ in MES-HL5 medium was pulsed with $25 \mathrm{mCi}$ of carrier-free ${ }^{32} \mathrm{PO}_{4}$ for $105 \mathrm{~min}$ at $22^{\circ} \mathrm{C}$. Cells were then pelleted, washed twice with MES-HL5 medium containing $25 \mathrm{mM} \mathrm{NaPO}$, and suspended at $10^{6}$ cells per $\mathrm{ml}$ in MES-HL5 containing $25 \mathrm{mM} \mathrm{NaPO}_{4}$ to initiate the chase. Aliquots $(7 \mathrm{ml})$ of the culture were withdrawn at 30 - to 180-min intervals for isolation of whole-cell RNA. To monitor the chase, acid-precipitable radioactivity associated with whole cells and with isolated RNA was determined for each time point. $T_{0}$ of the chase is defined as the time point at which there was no further increase in acid-precipitable radioactivity in whole-cell RNA. Routinely, this occurred within 30 to $60 \mathrm{~min}$ after suspension of the cells in highphosphate medium.

Purification of labeled poly $(A)^{+}$RNA. Poly $(A)^{+}$RNA was $^{+}$ isolated by two rounds of batch absorption to and elution from oligo(dT)-cellulose. ${ }^{32} \mathrm{P}$-labeled whole-cell RNA from each time point was added to $25 \mathrm{mg}$ of prewashed oligo(dT)cellulose in binding buffer $(20 \mathrm{mM}$ Tris hydrochloride, $\mathrm{pH}$ 7.6, 0.5 M NaCl, $1 \mathrm{mM}$ EDTA, $0.1 \%$ sodium dodecyl sulfate) in a microcentrifuge tube $(1.5 \mathrm{ml})$ and incubated at room temperature for 15 min while shaking. After several washes with wash buffer (same as binding buffer except $\mathrm{NaCl}$ was reduced to $100 \mathrm{mM})$, the poly $(\mathrm{A})^{+}$RNA was eluted with three washes of elution buffer $(10 \mathrm{mM}$ Tris hydrochloride, $\mathrm{pH} 7.5,1 \mathrm{mM}$ EDTA, $0.05 \%$ sodium dodecyl sulfate) at $37^{\circ} \mathrm{C}$. The oligo(dT)-cellulose was then treated with $100 \mathrm{mM}$ $\mathrm{NaOH}-5 \mathrm{mM}$ EDTA and subsequently reequilibrated in binding buffer. After the $\mathrm{NaCl}$ concentration was adjusted to $500 \mathrm{mM}$ with $5 \mathrm{M} \mathrm{NaCl}$, the poly $(\mathrm{A})^{+} \mathrm{RNA}$ was rebound to the oligo(dT)-cellulose, and the resin was rewashed and re-eluted as described above. The poly $(\mathrm{A})^{+}$RNA was recovered by ethanol precipitation and dissolved in $\mathrm{H}_{2} \mathrm{O}$, and its concentration was determined by measuring the $A_{260}$. Typically, 2.0 to $6.0 \mu \mathrm{g}$ of $\operatorname{poly}(\mathrm{A})^{+}$RNA was recovered from each 7.0-ml aliquot of cells. The specific activity of the poly $(\mathrm{A})^{+}$RNA recovered from the pulsed cells at the end of the labeling period was routinely $1.0 \times 10^{5}$ to $2.0 \times 10^{5}$ $\mathrm{cpm} / \mu \mathrm{g}$.

Dot blots. Half-lives of individual mRNAs were determined by hybridization of poly $(\mathrm{A})^{+}$RNA, labeled in a

TABLE 1. Properties of selected plasmids

\begin{tabular}{|c|c|c|c|c|c|c|}
\hline \multirow{3}{*}{$\begin{array}{l}\text { Plasmid } \\
\text { designation }\end{array}$} & \multirow{3}{*}{$\begin{array}{l}\text { Selection } \\
\text { group }\end{array}$} & \multirow{3}{*}{$\begin{array}{c}\text { Cloned } \\
\text { fragment } \\
\text { size } \\
(\mathrm{kbp})\end{array}$} & \multicolumn{4}{|c|}{ Encoded mRNA } \\
\hline & & & \multirow{2}{*}{$\begin{array}{l}\text { Size } \\
(\mathbf{k b})\end{array}$} & \multicolumn{2}{|c|}{ Half-life (h) } & \multirow{2}{*}{$\begin{array}{l}\text { Stability } \\
\text { class }^{c}\end{array}$} \\
\hline & & & & Measured & Corrected $^{b}$ & \\
\hline p2 & s & 0.50 & 1.10 & 16.0 & 9.6 & $S$ \\
\hline p4 & 1 & 0.33 & 0.88 & 1.5 & 0.9 & $\mathrm{U}$ \\
\hline p10 & $\mathbf{s}$ & 0.26 & 0.40 & 6.5 & 3.9 & MS \\
\hline p14 & $\mathbf{s}$ & 0.73 & 0.64 & 5.0 & 3.0 & MS \\
\hline p22 & $\mathbf{s}$ & 0.28 & 0.50 & 7.0 & 4.2 & MS \\
\hline p23 & $\mathbf{s}$ & 1.10 & 1.10 & 10.0 & 6.0 & MS \\
\hline p24 & $\mathbf{s}$ & 0.50 & 0.68 & 16.0 & 9.6 & $S$ \\
\hline p29 & $\mathbf{s}$ & 0.33 & 0.41 & 6.0 & 3.6 & MS \\
\hline p31 & 1 & 0.60 & 1.50 & 3.0 & 1.8 & $\mathrm{U}$ \\
\hline p32 & s & 0.18 & 0.50 & 13.0 & 7.8 & $S$ \\
\hline PST-3 & $r$ & 2.20 & 1.10 & 1.5 & 0.9 & $\mathrm{U}$ \\
\hline $\begin{array}{l}\text { pcDd actin } \\
\text { B1 }\end{array}$ & $\mathrm{r}$ & 1.05 & $\begin{array}{l}1.25 \\
1.35\end{array}$ & 1.5 & 0.9 & $\mathrm{U}$ \\
\hline NS28 & $r$ & 0.18 & 0.94 & 2.5 & 1.5 & $\mathrm{U}$ \\
\hline PSK80 & $r$ & 0.88 & 1.90 & 1.9 & 1.1 & $\mathrm{U}$ \\
\hline
\end{tabular}

${ }^{a}$ Selection group: nature of probe used in original selection. $\mathrm{s}$, Probe from mRNA with short poly(A); I, probe from mRNA with long poly(A); r, random clones from existing stocks, not screened with either probe.

${ }^{b}$ Corrected for efficiency of chase as described in the text.

c S, Stable; MS, moderately stable; U, unstable. 
pulse-chase experiment, to nitrocellulose filters containing excess plasmid DNA. Plasmid DNA was denatured at $85^{\circ} \mathrm{C}$ in $200 \mathrm{mM} \mathrm{NaOH}$ for $5 \mathrm{~min}$, placed on ice, neutralized, and then adjusted to $6.6 \times \mathrm{SSC}(1 \times \mathrm{SSC}$ is $0.15 \mathrm{M} \mathrm{NaCl}$ plus $0.015 \mathrm{M}$ sodium citrate). The denatured plasmid DNA was applied to Schleicher \& Schuell nitrocellulose (prewet in $2 \times$ SSC) encased in a Schleicher \& Schuell dot blot manifold. The nitrocellulose was first washed with $2 \times$ SSC followed by two dilution series of the DNA such that $3,1.5,0.5$, and 0.1 $\mu \mathrm{g}$ or $5,2.5,1,0.1$, and $0.01 \mu \mathrm{g}$ of DNA was loaded in duplicate for each cDNA clone examined. Since air drawn through the dot blot apparatus tends to dry out the nitrocellulose, which leads to uneven DNA binding, no more than eight dots at a time were prewashed with $2 \times$ SSC prior to the addition of the DNA dilutions. After application of the DNA, each dot was washed with $500 \mu \mathrm{l}$ of $6 \times$ SSC. The nitrocellulose sheet was then air dried for $1 \mathrm{~h}$ and baked at $80^{\circ} \mathrm{C}$ in vacuo for $2 \mathrm{~h}$. A filter containing duplicate dilutions of up to 11 cDNA plasmids and one vector control was prepared for each time point of the pulse-chase experiments. The filters were placed in sealable plastic bags (a maximum of two filters per bag, back to back) and prehybridized in $10 \mathrm{ml}$ of $50 \%$ formamide $-4 \times \mathrm{SSC}$ for $15 \mathrm{~min}$ at $45^{\circ} \mathrm{C}$. A constant mass of ${ }^{32}$ P-labeled poly (A) ${ }^{+}$RNA $(1.5$ to $3.0 \mu \mathrm{g})$ from each time point of the experiment was heated to $65^{\circ} \mathrm{C}$ for $5 \mathrm{~min}$, quickly cooled on ice, and hybridized to the filters, in the same buffer, for $48 \mathrm{~h}$ at $45^{\circ} \mathrm{C}$.

After the hybridization, the filters were removed from the bags and washed twice at room temperature with $2 \times$ SSC $-0.1 \%$ sodium dodecyl sulfate and twice with $0.2 \times$ SSC $-0.1 \%$ sodium dodecyl sulfate ( 30 min per wash). The filters were then covered on both sides with a layer of plastic wrap and placed under film with an intensifying screen (Du Pont Cronex Lightning-Plus) at $-80^{\circ} \mathrm{C}$. Exposure times varied from $6 \mathrm{~h}$ to 5 days. The exposed films were quantitated by densitometry, using a Helena Laboratories Quick Scan $\mathrm{R}+\mathrm{D}$ densitometer. Peak heights of all scans were measured, and the values for all dots which exhibited a hybridization plateau were averaged and corrected for nonspecific hybridization to the vector sequences alone. The decay curve was determined from a semilog plot of the percentage of hybridization remaining at different times after the start of the chase.

Analysis of ribosome loading. For individual mRNAs, the mean polysome size and the fraction of the mRNA associated with polysomes were determined by fractionation of cytoplasmic extracts on 15 to $50 \%$ sucrose gradients followed by northern blotting analysis of the RNA associated with each gradient fraction. Details of this procedure have been described elsewhere (83). Autoradiographs were quantitated by densitometry, and the data are expressed as the percentage of the total autoradiographic exposure associated with each fraction of the gradient.

Measurement of poly(A) tract lengths. Whole-cell RNA extracted from vegetative amoebae was separated into fractions of increasing poly (A) length by thermal elution from poly(U)-Sepharose. Fractionation was as described previously (59) except that a final wash with LS buffer at $65^{\circ} \mathrm{C}$ replaced the $\mathrm{EB}$ wash at $55^{\circ} \mathrm{C}$. Average poly(A) tract lengths associated with each column fraction were determined by 3 '-end labeling, digestion with RNases $A$ and $T_{1}$, and gel electrophoresis of the digestion products, as previously described (83). The distribution of individual mRNAs in the different poly(A) size classes was determined by RNA dot blotting. Duplicate samples $(0.5 \mu \mathrm{g})$ of RNA from each of the column eluates were incubated in denaturation buffer $(5 \mathrm{mM}$
NaOAc, 1 mM EDTA, $20 \mathrm{mM}$ MOPS [morpholinepropanesulfonic acid], $6 \%$ formaldehyde, $50 \%$ formamide) at $65^{\circ} \mathrm{C}$ for $5 \mathrm{~min}$ and applied to Zeta-Probe (Bio-Rad Laboratories) membranes previously and subsequently washed with $2 \times$ and $6 \times$ SSPE (82), respectively. Filters were hybridized to high-specific-activity cDNA probes essentially as described for northern blots. Autoradiographs were quantitated by densitometry, and the data are expressed as the percentage of the total autoradiographic exposure associated with each column fraction.

Other procedures. Plasmid DNA was purified by scaling up the miniprep method of Birnboim and Doly (6). Details of this modified procedure have been reported elsewhere (82).

Northern blots were prepared from small, thin $(16.5 \mathrm{ml}$; 6.5 by $8.5 \mathrm{~cm}$ ) agarose-formaldehyde gels cast and run as described by Rave et al. (65). Gels were blotted onto nitrocellulose sheets as described by Alwine et al. (2) and hybridized with nick-translated (55) plasmid DNA as described elsewhere (Shapiro, Ph.D. thesis).

For DNA blots, D. discoideum nuclear DNA (30) was digested with restriction endonuclease EcoRI or PstI, electrophoresed through $0.7 \%$ agarose gels (62), denatured in 0.5 $\mathrm{M} \mathrm{NaOH}-0.5 \mathrm{M} \mathrm{NaCl}$, neutralized, and transferred to nitrocellulose sheets $(\mathbf{8 0})$. Blots were hybridized, washed, and subjected to autoradiographic exposure as described elsewhere (Shapiro, Ph.D. thesis). (82).

Hybrid selection of mRNAs was as described previously

\section{RESULTS}

Pulse-chase assay for mRNA decay rates. Relative decay rates of individual $\mathrm{mRNAs}$ were determined by labeling cells in a ${ }^{32} \mathrm{PO}_{4}$ pulse-chase, isolating the labeled poly $(\mathrm{A})^{+} \mathrm{RNA}$, and then exhaustively hybridizing the RNA to specific cloned DNAs. Amoebae in MES-HL5 medium were pulsed with ${ }^{32} \mathrm{PO}_{4}(500 \mu \mathrm{Ci} / \mathrm{ml})$ for $105 \mathrm{~min}$ and then washed and suspended in MES-HL5 medium containing $25 \mathrm{mM} \mathrm{NaPO}_{4}$. At different times after the onset of the chase, total cellular RNA was isolated and fractionated on oligo(dT)-cellulose, and the purified poly $(\mathrm{A})^{+}$RNA was hybridized to a series of dilutions of cloned DNA in duplicate dots spotted on nitrocellulose filters. After hybridization and washing, the filters were exposed to X-ray film and the resultant autoradiograms were scanned with a densitometer. An average optical density was derived from the scans of those dots which contained excess DNA, i.e., those dots for which an increase in DNA concentration did not lead to an increase in hybridized RNA.

To minimize nonspecific hybridization backgrounds, we have restricted our half-life measurements to the poly $(\mathrm{A})^{+}$ population of mRNA. It could be argued that this approach might miss a significant poly(A)-deficient mRNA population which arises from the metabolism of poly $(\mathrm{A})^{+}$mRNAs. However, several observations indicate that our focus on polyadenylated RNAs is valid. (i) poly(A) ${ }^{-}$RNA, purified by poly(U)-Sepharose chromatography, has $<1 \%$ of the translational activity of poly (A) ${ }^{+}$RNA and an extremely low complexity (59), (ii) studies of the metabolism of the poly(A) tracts on Dictyostelium mRNAs indicate that mRNAs are initially synthesized with long poly(A) tracts which shorten to a steady-state length of 40 to 60 adenylate residues (58-60); and (iii) $3^{\prime}$ ends present on individual mRNAs have been isolated and shown to be primarily confined to poly(A) tracts of the aforementioned steady-state lengths (83).

Hybridization of ${ }^{32} \mathrm{P}$-labeled mRNA to dots of pcDd actin 


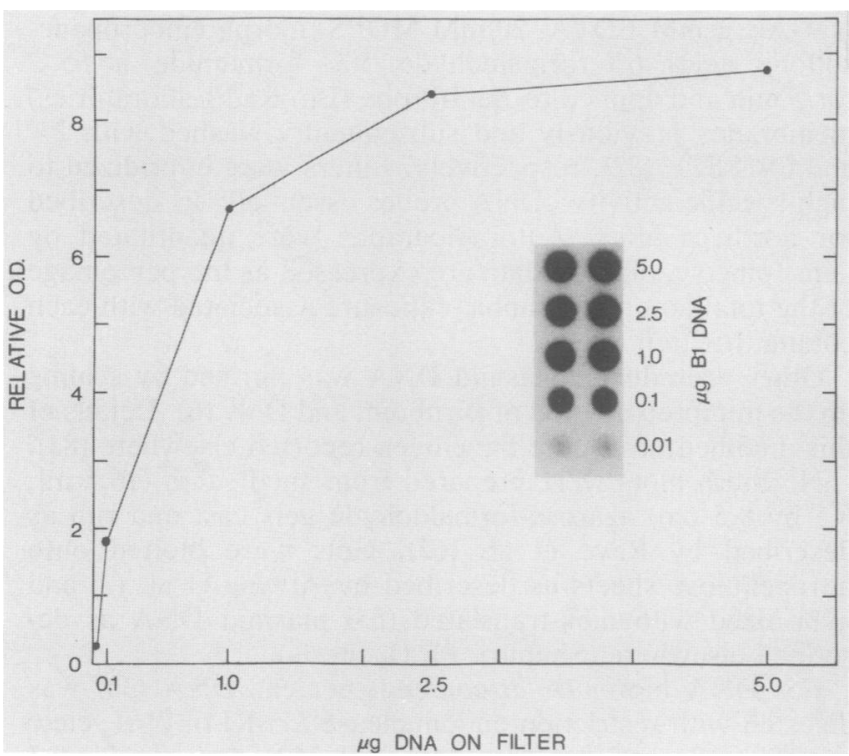

FIG. 1. Hybridization to dots containing different amounts of plasmid DNA. Different amounts of denatured DNA from plasmid pcDd actin B1 were spotted in duplicate onto a nitrocellulose filter and hybridized to ${ }^{32} \mathrm{P}$-labeled mRNA isolated from cells which had been labeled for $105 \mathrm{~min}$ with ${ }^{32} \mathrm{PO}_{4}(500 \mu \mathrm{Ci} / \mathrm{ml})$. The filters were placed under X-ray film, and the extent of hybridization to each dot was quantitated by densitometry of the resultant autoradiograms. Each data point represents the average optical density (O.D.) (in arbitrary units) of the duplicate measurements. (Inset) Photograph of the actual autoradiogram.

B1 DNA is shown in Fig. 1. In this experiment DNA excess has been reached at approximately $2.5 \mu \mathrm{g}$ of DNA per dot. A half-life determination for a specific mRNA consists of a series of such dot blot hybridizations with ${ }^{32} \mathrm{P}$-labeled poly $(\mathrm{A})^{+}$RNA isolated at different times after the onset of the chase. Figure 2 shows such a set of dot blots for the half-life determination of actin mRNA. A plot of the hybridization to the DNA excess dots versus the time of chase yields a half-life for a given mRNA. Figure 3 shows the results

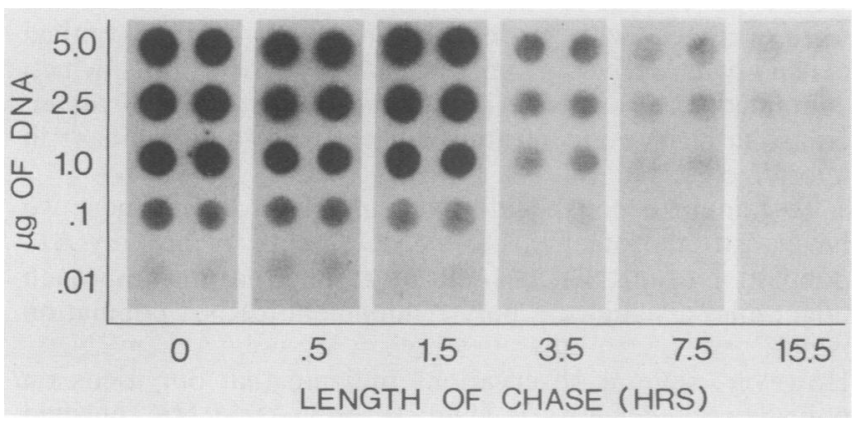

FIG. 2. Hybridization of actin mRNA to DNA dots at different times during the course of a ${ }^{32} \mathrm{PO}_{4}$ pulse-chase. A set of identical nitrocellulose filters, each containing duplicate dots of different amounts of denatured DNA from plasmid pcDd actin B1, was prepared as described in the text. Each filter was hybridized to a different aliquot of labeled mRNA isolated from cells at the indicated time points during the course of the chase. After hybridization and washing, the filters were all exposed to X-ray film for the same length of time. Shown is a composite photograph of the autoradiograms obtained from the hybridization of actin mRNA to each set of dots.

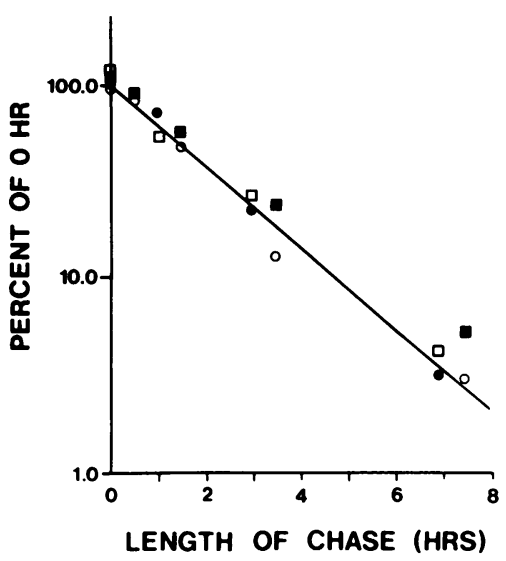

FIG. 3. Actin mRNA half-life measurements. The amount of labeled actin mRNA present in cells during the course of a phosphate chase was determined in two independent experiments identical to that described in the legend to Fig. 2. The data were quantitated by densitometry of the autoradiograms and subsequently by liquid scintillation spectrometry. For the latter, the same filters were cut into a set of small squares, each encompassing one dot, and the extent of hybridization to each dot was then determined by scintillation counting. The values for all dots at a given time point which exhibited a saturated level of hybridization were averaged and corrected for nonspecific hybridization to vector sequences. The data are plotted as the percentage of the hybridization signal remaining after the start of the chase. Symbols: $O, \square$, experiment 1 ; $\boldsymbol{Q}, \mathbf{\square}$, experiment 2 ; quantitation by densitometry $(O, 0)$ or scintillation counting $(\square, \square)$.

of two independent half-life determinations for actin mRNA and a comparison of the results obtained when the DNA dots are quantitated by densitometry of autoradiograms or by direct scintillation spectrometry. Both experiments and both methods of quantitation yield the same results: actin mRNA decays with first-order kinetics and an apparent half-life of $1.5 \mathrm{~h}$.

The first-order decay kinetics of actin mRNA indicate that a uniform chase has been obtained, but they do not provide a measure of the effectiveness of the chase (i.e., the extent of continued incorporation of ${ }^{32} \mathrm{PO}_{4}$ during the chase). A more accurate measure of the decay rate of actin mRNA (and other mRNAs) is obtained by correcting for the decay rate of stable RNA species. In a completely effective chase, the measured decay rate of stable RNAs should be equal to the cell generation time. This is observed in uridine pulse-chase experiments (R. E. Manrow and A. Jacobson, unpublished experiments). When cells are pulse-labeled with ${ }^{32} \mathrm{PO}_{4}, 85$ to $90 \%$ of the ${ }^{32} \mathrm{PO}_{4}$ label at $\mathrm{T}_{0}$ is in rRNA and tRNA (data not shown). Therefore, the decay of the stable RNAs is effectively measured as the decay in specific activity of total cellular RNA, and a correction factor can be derived by comparing the rate of decay of the specific activity of total cellular RNA with the cell doubling time. In the experiments reported here, the cell doubling time was $9 \mathrm{~h}$ and the average $t_{1 / 2}$ for the specific activity of total cellular RNA was $14 \mathrm{~h}$. The half-lives of mRNAs measured by this approach can thus be more closely approximated by multiplying the measured half-lives by 0.6 (i.e., $9 / 14$; the expected $t_{1 / 2}$ for total RNA/the actual $t_{1 / 2}$ for total RNA). For actin mRNA the corrected half-life is thus $0.9 \mathrm{~h}$. Multiplying each of the 14 mRNA half-lives measured here (see below) by 0.6 yields a set of half-lives which range from approximately $50 \mathrm{~min}$ to approximately $10 \mathrm{~h}$. These values are coincident with the range of half-lives observed for the entire population of $D$. 
discoideum mRNAs in a completely effective uridine pulsechase (14), leading us to conclude that the corrected values reliably reflect the relative decay rates of individual mRNAs.

To avoid the necessity of making these corrections, it would seem possible to increase the effectiveness of the chase by increasing the phosphate concentration of the growth medium. We have examined this alternative and found that higher phosphate concentrations do lead to somewhat more effective chases (data not shown), but increased phosphate concentrations markedly reduce cellular growth rates (data not shown). Since it is not clear that the decay rates of all mRNAs will change equivalently in response to a change in growth rate $(54,63)$, we have not explored this option further.

Half-lives of individual mRNAs. Half-lives of the mRNAs encoded by the selected cDNA clones as well as a genomic DNA clone (PST3) complementary to the developmentally regulated cDNA clone pcDdI-42 (70) and two other cDNA clones (NS28 and PSK80) were determined by the methods described above. These mRNAs showed first-order decay rates with apparent half-lives ranging from 1.5 to $16 \mathrm{~h}$ (Fig. 4; Table 1). After normalizing for the decay rate of stable RNAs (see above), the half-lives ranged from 0.9 to $9.6 \mathrm{~h}$ (Table 1). As noted above, this range of half-lives is similar to that observed previously for the decay of total poly $(\mathrm{A})^{+}$ RNA (14), suggesting that the complex decay kinetics observed for total poly $(A)^{+}$RNA reflect the sum of the decay rates of individual mRNAs and that the uniform 4- to 5-h half-life observed for total cellular mRNA in vegetative cells treated with intercalating drugs $(18,47)$ does not accurately reflect the actual diversity of mRNA decay rates.

Table 1 summarizes the half-lives and other properties of the mRNAs we have characterized. For the purposes of discussion, the mRNAs have been classified as stable (corrected $t_{1 / 2}>7 \mathrm{~h}$ ), moderately stable (corrected $t_{1 / 2}=3$ to 7 h), and unstable (corrected $t_{1 / 2}<3 \mathrm{~h}$ ).

Relative decay rates of actin mRNAs. Although the data of Fig. 3 indicate a first-order decay rate for actin mRNA, these data actually reflect the average decay rate of the transcripts of at least 15 different actin genes $(35,67)$. All of these transcripts exhibit considerable homology from their $5^{\prime}$ ends to the ends of their coding regions, but differentiate into two classes on the basis of the size and sequence of their 3 '-UTs (67). The two classes, 1.35- and 1.25-kilobase (kb) mRNAs, are present in approximately equimolar amounts in steadystate mRNA from vegetative amoebae $(4,67)$. To determine whether the two size classes of actin mRNA decayed at the same rate, we compared the relative labeling of the 1.35- and 1.25-kb mRNAs in a pulse-chase experiment (Fig. 5). Actin mRNAs were hybrid selected from RNA isolated at $0,0.5$, and $2.0 \mathrm{~h}$ of a pulse-chase, resolved by gel electrophoresis and autoradiography, and quantitated by densitometric scanning of the autoradiographs. Although the 1.25 - and $1.35-\mathrm{kb}$ forms of the mRNA are equally represented by $2 \mathrm{~h}$ of the chase, the larger class of actin mRNAs is initially overrepresented in the pulse and underrepresented in the early part of the chase (Fig. 5A). This change in relative labeling of the two mRNAs appears to be due to differences in their relative decay rates (Fig. 5B). Whereas the $1.25-\mathrm{kb}$ actin mRNAs decay with relatively simple kinetics $\left(t_{1 / 2}, \sim 1.25 \mathrm{hs}\right)$, the decay kinetics of the $1.35-\mathrm{kb}$ species are more complex. The majority of the mRNA decays with a half-life of approximately $0.33 \mathrm{~h}$, and the remainder has a half-life approximately 10 -fold longer. We have not determined whether the complex decay kinetics of the 1.35-kb mRNAs reflect differences in the decay rates of $1.35-\mathrm{kb}$ subspecies or changes in the decay rates of the entire set of $1.35-\mathrm{kb} \mathrm{mRNAs}$. These results suggest that the $1.35-\mathrm{kb}$ mRNAs achieve equimolarity with the $1.25-\mathrm{kb}$ mRNAs by being synthesized and turned over at higher rates and raise the possibility that the $3^{\prime}$-UT region of the $1.35-\mathrm{kb}$ mRNAs may contain a site which targets them for more rapid degradation.

mRNA decay rates versus mRNA size. Previous experiments have suggested that mRNA length (i.e., target size) may correlate inversely with mRNA stability $(39,52,58,63$, $72,78,81)$. Therefore, RNA blot analysis was used to measure the size of each of the mRNAs for which we determined a decay rate. The data of Fig. 6 indicate that no correlation of mRNA size and stability was observed.

mRNA decay rates versus poly $(A)$ tail length. The possibility that poly $(A)$ tail lengths directly determine mRNA stabilities has been suggested by some experiments $(28,56,86$, $90)$, but not by others $(16,38,58,71,84)$. To evaluate whether poly(A) tail lengths influence mRNA decay rates in D. discoideum amoebae, we have compared the steady-state poly(A) tail length of seven mRNAs with different half-lives (Fig. 7). Total cellular mRNA was fractionated on the basis of poly(A) tail length by thermal elution from poly(U)Sepharose (59). The average poly(A) lengths associated with the flowthrough and $25,35,45,55$, and $65^{\circ} \mathrm{C}$ eluates are approximately $0,15,35,60,85$, and 110 adenylate residues, respectively (59; D. Blinder and A. Jacobson, unpublished observations). The distribution of individual mRNAs in the different poly(U)-Sepharose eluates was measured by RNA dot blotting and hybridization with cloned DNAs. The data of Fig. 7 indicate that, for three of four unstable mRNAs (actin B1, PST-3, and p4), approximately $50 \%$ or more of the mRNA is present in long poly $(A)$ fractions $\left(55\right.$ and $\left.65^{\circ} \mathrm{C}\right)$ and for two of three stable and moderately stable mRNAs (p24 and p32) $>60 \%$ of the mRNA is associated with the short poly(A) fractions (flowthrough, 25,35 , and $45^{\circ} \mathrm{C}$ ). For actin mRNA, and for the mRNAs encoded by p24 and p29, these $\operatorname{poly}(\mathrm{A})$ size measurements have been confirmed by a higherresolution technique involving hybrid selection of the mRNA, labeling of the mRNA $3^{\prime}$ terminus, and direct isolation and sizing of the labeled poly $(\mathrm{A})$ tract $(83 ; \mathrm{D}$. Blinder, L. F. Steel, and A. Jacobson, unpublished experiments). The low relative abundance of most of the other mRNAs in this study precluded their evaluation by this alternative method. The results of Fig. 7 indicate that, in general, but not always, stable mRNAs have shorter average poly(A) tail lengths than unstable mRNAs. This is further illustrated by an experiment in which the actin mRNAs present in the poly(U)-Sepharose $24,35,45$, and $55^{\circ} \mathrm{C}$ eluates have been characterized by northern blotting. Figure 8 shows that the larger (1.35-kb) actin mRNAs, shown (above) to be less stable than the smaller $(1.25-\mathrm{kb})$ actin mRNAs, are preferentially associated with the higher-temperature eluates, i.e., with the longer poly(A) fractions. Collectively, these data are consistent with a uniform, time-dependent shortening of most mRNA poly(A) tracts to a steady-state length of 40 to 60 adenylate residues $(51,58-60,66,75)$ and do not support a role for poly(A) as a stability determinant.

Translational efficiency of stable, moderately stable, and unstable mRNAs. Assuming a constant rate of translational elongation and termination, translational efficiency can be indirectly measured as the rate of ribosome loading. If, as has been postulated $(1,26,33,41,45)$, the stability of a given mRNA is determined by its translational efficiency, then one would expect stable mRNAs to be found on polysomes to a greater extent than unstable mRNAs and to be found on larger polysomes than unstable mRNAs of the same length. 

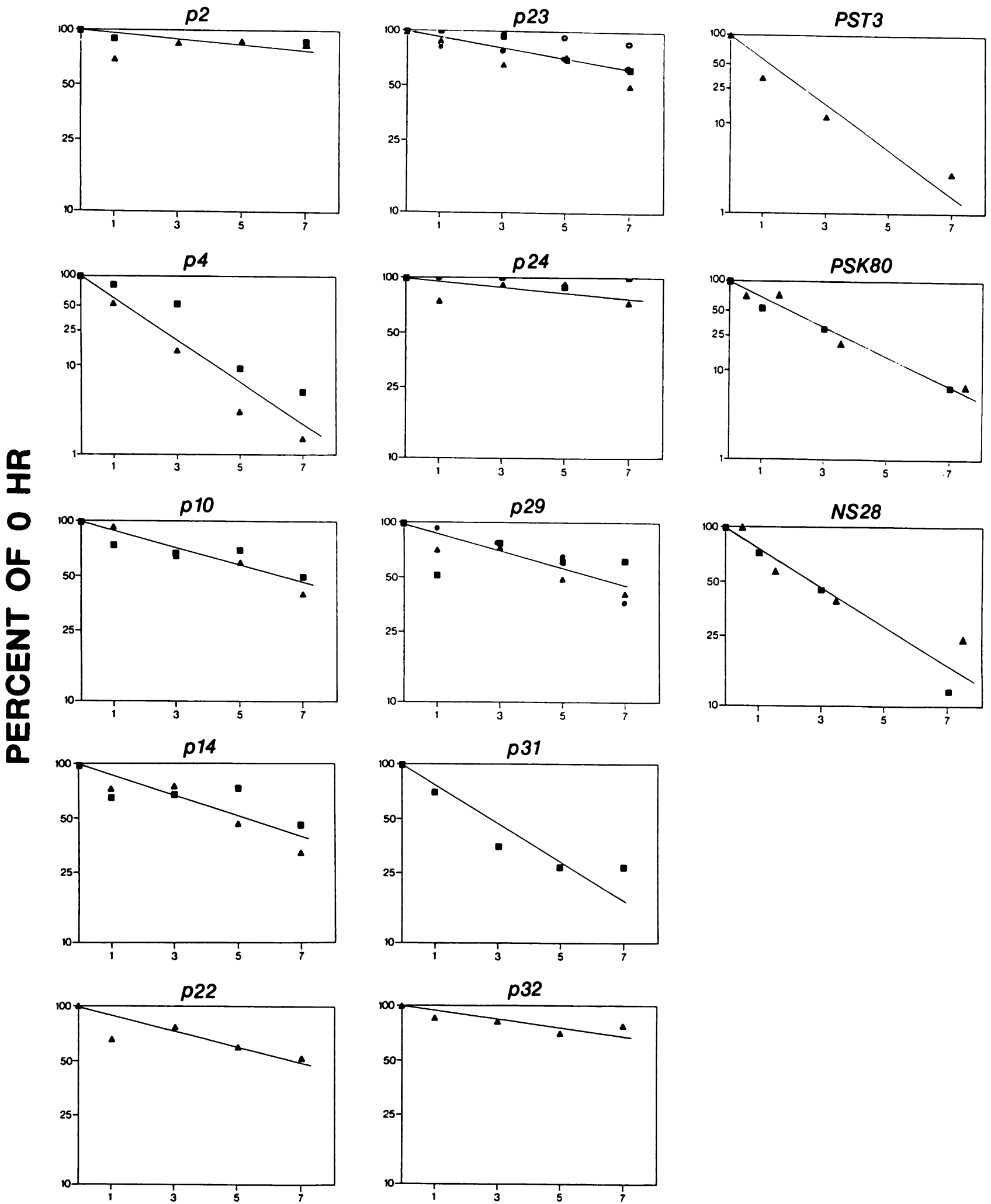

\section{LENGTH OF CHASE (HRS)}

FIG. 4. mRNA half-life measurements. Denatured plasmid DNA was bound to nitrocellulose and hybridized to poly(A) ${ }^{+}$RNA labeled in a pulse-chase experiment as described in Materials and Methods. The intensity of the hybridization signal of each dot was quantitated by densitometry, and the values for all dots at a given time point which exhibited a saturated level of hybridization were averaged and corrected for nonspecific hybridization to the vector sequences alone. The data were plotted as the percentage of the hybridization signal remaining after the start of the chase. Different symbols represent independent experiments, and the decay curves represent the best fit through the data points of all experiments. Note that the mRNAs encoded by p4, PST3, and PSK80 had faster decay rates than all other mRNAs and necessitated the use of a different $y$-axis scale to plot the data. 
To explore these possibilities, we have fractionated cytoplasmic extracts on sucrose gradients and utilized northern blotting to analyze the polysomal distributions of 12 mRNAs differing in decay rates. Figure 9 shows the relative percentages of individual unstable (part A), moderately stable (part B), and stable mRNAs (part C) associated with each gradient fraction. All of the mRNAs are primarily associated with polysomes, although the extent of ribosome loading and the average polysome sizes differ for different mRNAs. The number of ribosomes associated with each mRNA in its respective peak polysomal fraction was compared with the size of each mRNA (Fig. 10). The data of Figure 10 indicate a direct correlation between mRNA length and number of associated ribosomes and show no significant differences in the number of ribosomes per unit length of stable, moderately stable, and unstable mRNAs. We conclude that the stability of these mRNAs is not related to their translational efficiency. It could be argued that these data are a fortuitous consequence of large differences in the ratio of coding/noncoding sequences in mRNAs of different stabilities. However, experiments in which we have identified the translation products of several of these mRNAs by hybrid selection and in vitro translation indicate a good correlation between mRNA size and translation product size $(82,83$; Blinder et al., unpublished experiments).

A significant difference between stable and unstable mRNAs is observed with respect to the proportion of the individual mRNAs actually associated with ribosomes. Figure 11 indicates that there is a direct correlation between the steady-state percentage of a given mRNA that is found in polysomes and its degree of instability; i.e., unstable mRNAs are more efficiently recruited into polysomes than

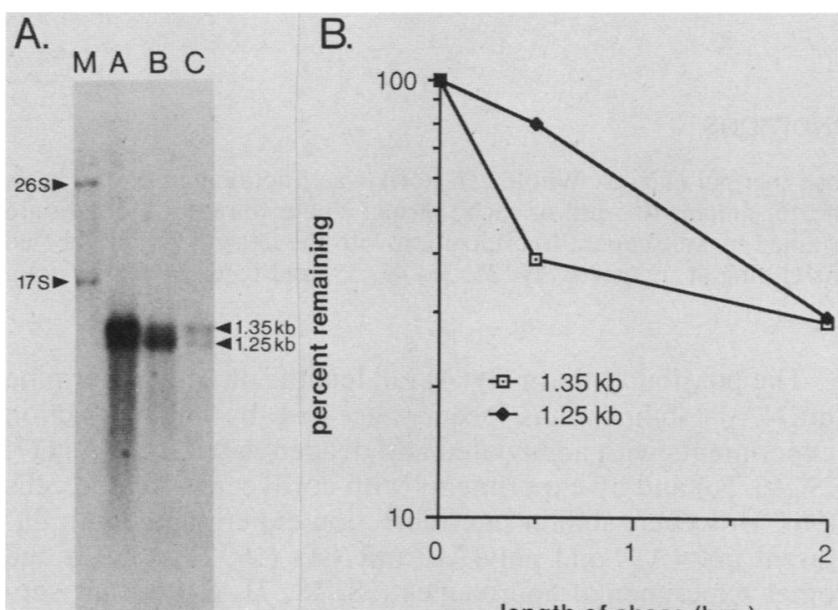

length of chase (hrs.)

FIG. 5. Pulse-chase analysis of actin mRNAs. (A) RNA was labeled in a pulse-chase experiment analogous to that in Fig. 2. With $10 \mu \mathrm{g}$ of denatured pcDd actin B1 DNA immobilized on nitrocellulose, actin mRNAs were hybrid selected from 2.5, 2.3, and $1.8 \mu \mathrm{g}$ of labeled poly $(A)^{+}$RNA from the 0-, 0.5-, and 2.0-h time points of the chase, respectively. The eluted RNA was separated on a $1.8 \%$ agarose-formaldehyde denaturing gel, dried, and autoradiographed. The $26 \mathrm{~S}$ and $17 \mathrm{~S}$ rRNAs in $100 \mathrm{cpm}$ of ${ }^{32} \mathrm{P}$-labeled poly(A)- RNA were used as size markers (lane $M$ ). The 1.35 - and 1.25 -kb populations of actin mRNAs are indicated. Lanes $A, B$, and $C$ contain actin mRNAs hybrid selected from the 0-, 0.5-, and 2.0-h samples, respectively. (B) Relative autoradiographic intensity of the 1.25 - and 1.35-kb actin mRNA bands was quantitated by scanning densitometry. The data were corrected for the different amounts of input mRNA used for hybrid selection (see above) and then plotted as described for Fig. 3 and 4.

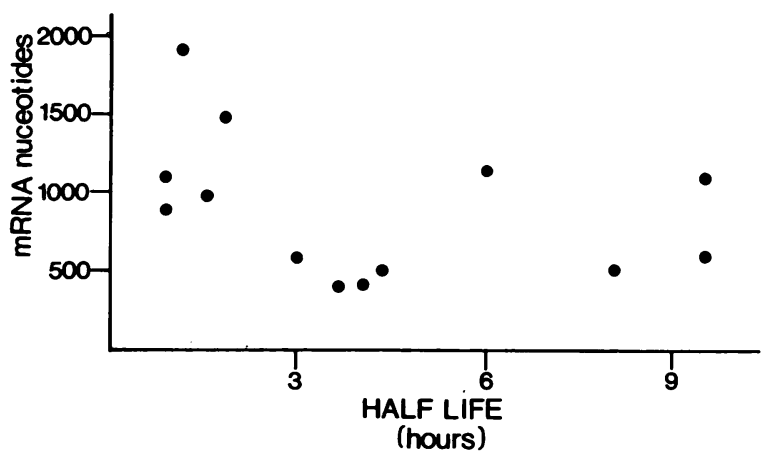

FIG. 6. mRNA decay rates versus mRNA size. Half-lives of individual mRNAs, determined in the experiments of Fig. 3 and 4 and corrected as in Table 1, are compared with the sizes of these mRNAs determined by northern blotting.

stable mRNAs. Over $95 \%$ of the most unstable mRNAs were found on polysomes, but only 70 to $75 \%$ of the most stable mRNAs were found on polysomes. (Since polysomal and nonpolysomal fractions of short mRNAs are inadequately resolved, mRNAs of $<0.5 \mathrm{~kb}$ are excluded from this analysis.) mRNAs of intermediate stability showed intermediate values for mRNA recruitment. These differences in mRNA recruitment are substantially magnified in cells with a reduced rate of translational initiation, i.e., in early developing cells. Figure 12 compares the polysomal distributions of a stable (p2) and an unstable (p4) mRNA in growing and early developing cells. Whereas $75 \%$ of the p2 mRNA was associated with ribosomes in growing cells, only $17 \%$ of that mRNA was associated with ribosomes in developing cells. The distribution of $\mathrm{p} 4 \mathrm{mRNA}$ was less drastically affected by development which reduces polysome association of the $\mathrm{p} 4$ mRNA from $>95$ to $72 \%$. We have observed a comparable, development-induced change in the distributions of another pair of stable and unstable mRNAs (p24 and actin) and roted that ribosome association can be restored by reducing elongation rates with low concentrations of cycloheximide (83). These results suggest that stable mRNAs are less efficiently recruited into polysomes because of a reduced capacity for translational initiation relative to unstable mRNAs.

\section{DISCUSSION}

In eucaryotic cells, the decay rates of individual mRNAs can differ from each other by more than an order of magnitude $(11,14,25,78,81)$. Moreover, the decay rates of some individual mRNAs can vary as a consequence of differentiation $(25,38,43)$, a particular stage of the cell cycle (79), or the presence of specific hormones (9) or specific inhibitors $(3,22)$. The mechanisms responsible for determining either the intrinsic decay rate of an mRNA or the regulation of that rate are unknown.

Several features of mRNA structure, including $5^{\prime}$ caps, $3^{\prime}$ poly(A) tails, mRNA size, and specific sequences within the transcript, have been examined with respect to their possible roles in determining mRNA stability. In general, there is good agreement that an intact $5^{\prime}$ cap is essential for mRNA stability, although the extent of destabilization attributable to decapping varies significantly for different mRNAs (17, $19,23,36,40,48)$. The hypothesis that mRNA stability is a function of target size was initially supported by studies of mRNA populations $(52,58,78,81)$. However, studies of mRNAs with coding region deletions $(20,22)$ and the data of Fig. 6 do not indicate any correlation between the size of an 

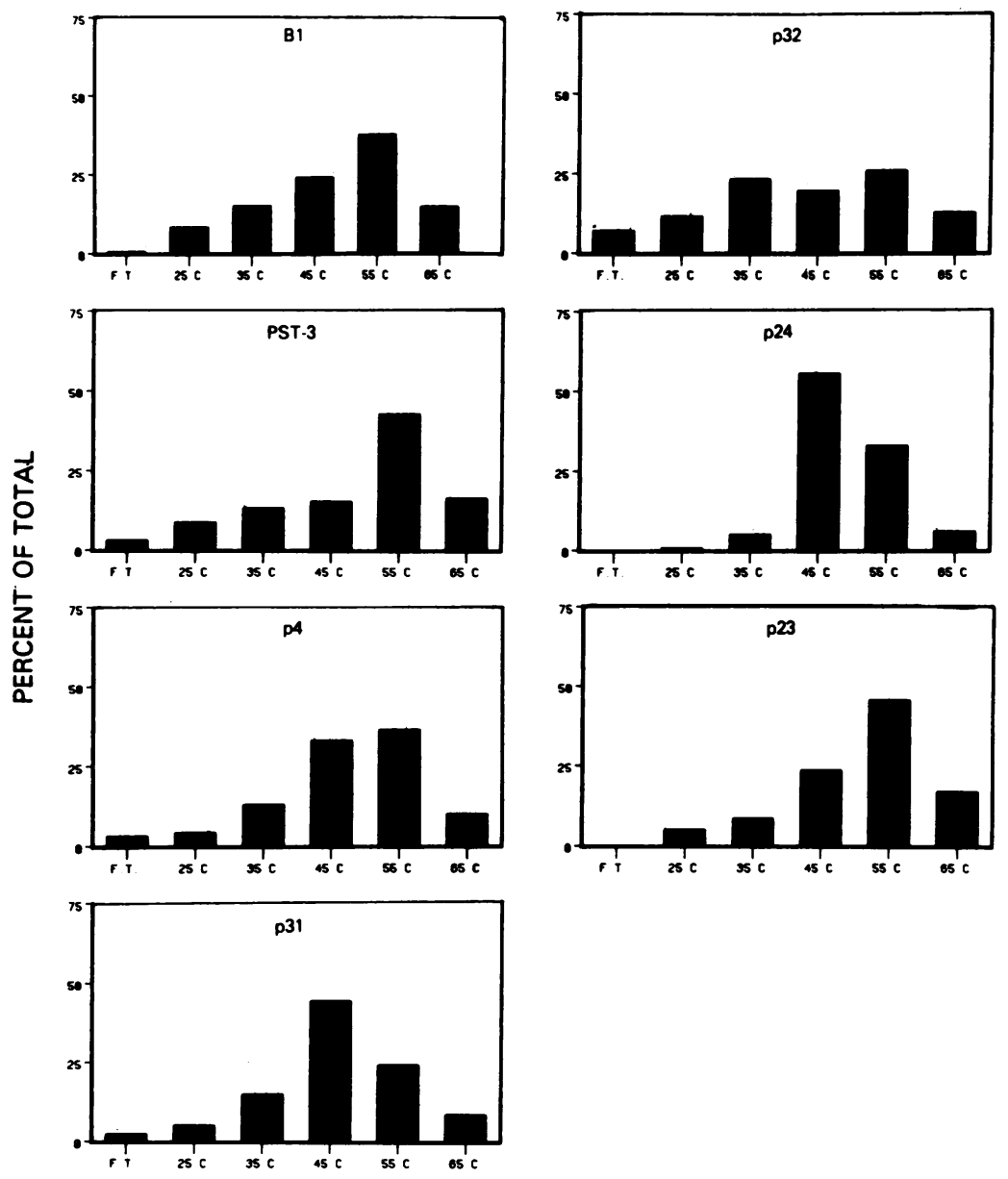

\section{ELUTION CONDITIONS}

FIG. 7. Relative percentage of individual mRNAs in poly(U)-Sepharose thermal eluates. Whole-cell RNA was fractionated on the basis of poly $(\mathrm{A})$ tract length by thermal elution from poly(U)-Sepharose. Duplicate samples $(0.5 \mu \mathrm{g})$ of each thermal eluate were dot blotted onto nitrocellulose, and the relative amounts of individual mRNAs were determined by subsequent hybridization with the designated ${ }^{32} \mathrm{P}-$ labeled DNAs. F.T., Flowthrough (unbound fraction); 25 to $65 \mathrm{C}$, RNA fractions eluting at, respectively, $25,35,45,55$, and $65^{\circ} \mathrm{C}$. B1 is the actin mRNA probe. All other plasmid designations are as given in Table 1.

individual mRNA and its stability. Our observations are not consistent with the results of similar experiments in Saccharomyces cerevisiae (72), but this discrepancy may be attributable to differences in the respective methods used to measure mRNA half-lives. Santiago et al. (72) inhibited transcription with high concentrations of 1,10-phenanthroline, a chelating agent which affects a number of cellular processes $(15,32,37)$ and which, therefore, may be unsuitable for the reliable measurement of mRNA decay rates.

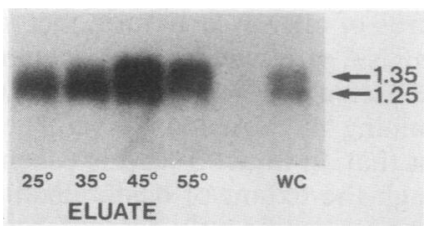

FIG. 8. Fractionation of actin mRNAs by thermal elution from poly(U)-Sepharose. Whole-cell (WC) RNA was fractionated by thermal elution from poly(U)-Sepharose. Aliquots $(0.5 \mu \mathrm{g})$ of the 25 , 35,45 , and $55^{\circ} \mathrm{C}$ eluates were characterized by northern blotting, using a ${ }^{32} \mathrm{P}$-labeled actin 6 DNA probe. The positions of the two major classes of actin mRNA are indicated (1.35 and 1.25).
The possibility that poly(A) tail lengths directly determine mRNA stabilities has been suggested by microinjection experiments with adenylated and deadenylated mRNAs (17, $29,46,56)$ and by experiments with cordycepin-treated cells (90). However, similar microinjection experiments with different poly(A) ${ }^{+}$and poly(A) ${ }^{-}$mRNAs $(16,27,48,73)$ and other experimental approaches $(38,58,71,84)$ do not support this hypothesis. Our measurements of the poly(A) tail lengths associated with individual stable and unstable $D$. discoideum mRNAs (Fig. 7 and 8$)(58,83)$ also show no direct correlation between the stability of an mRNA and the length of its poly(A) tail. Most of the evidence considered to support a relationship between poly(A) and mRNA stability has been derived from experiments in which mRNAs that are normally poly $(\mathrm{A})^{+}$either have been rendered poly $(\mathrm{A})^{-}$ or had their poly(A) tails shortened to well below steadystate lengths. The physiological significance of the use of such deadenylated mRNAs is unclear because (i) poly(A) tails normally do not shorten below a length of 40 to 65 nucleotides (Fig. 7) $(58,59,75)$; (ii) the decay curves of mRNAs with half-lives longer than the 4-h half-life $(58,59)$ for poly(A) shortening are linear, not biphasic (Fig. 4); and 
PERCENT OF TOTAL

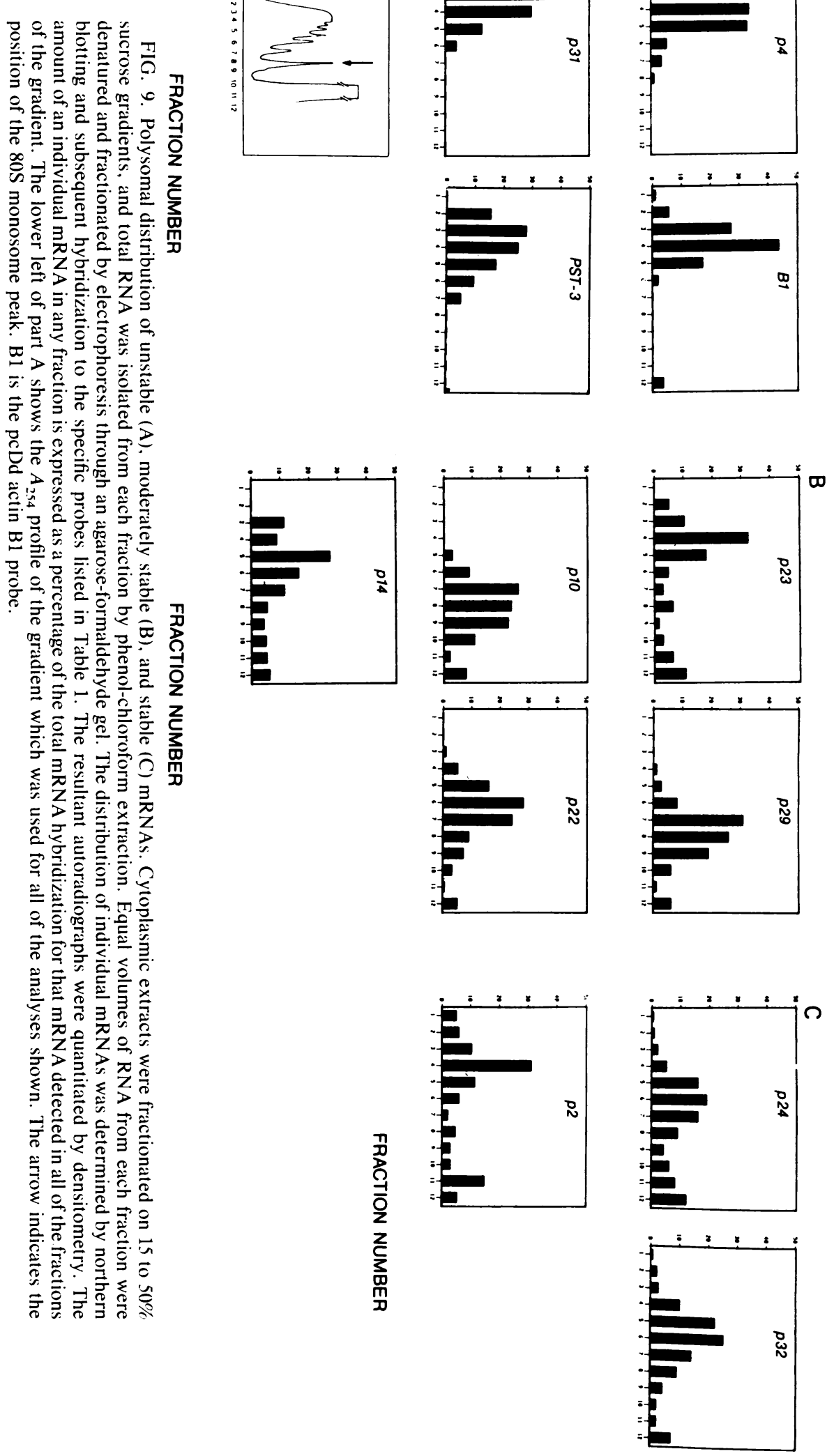




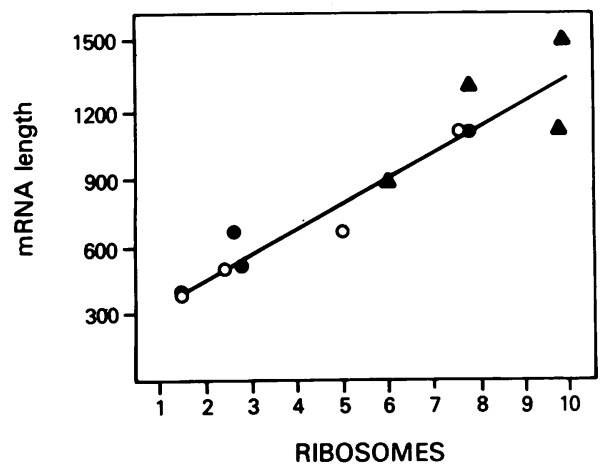

FIG. 10. Polysome sizes versus mRNA length. The number of ribosomes in the peak polysome fraction for each mRNA (from Fig. 9) is compared with the size of each mRNA, determined by northern blotting (Table 1). Symbols: 0 , stable mRNAs; $O$, moderately stable mRNAs; $\Delta$, unstable mRNAs.

(iii) poly(A)- mRNAs generally appear to be unique species of mRNA that are not derived from polyadenylated precursors in the cytoplasm $(7,21)$. Other experiments which support a role for poly(A) in mRNA stability are those which demonstrated that unstable poly $(A)^{-}$histone mRNAs were stabilized by the addition of poly(A) tails (28). These results are also of questionable significance in light of experiments (22) which demonstrate that degradation of histone mRNAs requires a $3^{\prime}$-end stem-loop structure.

The most significant determinants of stability may be located in the UT regions of mRNA. This was first suggested by the experiments of Ross and Pizarro (69) which demonstrated that two human globin mRNAs ( $\beta$ and $\delta)$, which are quite homologous in their coding and $5^{\prime}$-UT regions, differ substantially in their $3^{\prime}$-UT sequences and in their respective half-lives. Similar observations suggest that a determinant of mRNA instability may be located in the $3^{\prime}-\mathrm{UT}$ of the $1.35-\mathrm{kb}$ class of $D$. discoideum actin mRNAs (Fig. 5). Interestingly, all of the $1.35-\mathrm{kb}$, but none of the $1.25-\mathrm{kb}$, mRNAs have the sequence AGUGAUGAAAGUGCUUCUCACA (consensus) within their $3^{\prime}$-UT region (67). This sequence is particularly noteworthy in light of the extremely high $\mathrm{A}+\mathrm{T}$ content of noncoding regions in $D$. discoideum mRNAs (67). More definitive evidence for the importance of 5'- and $3^{\prime}$-UT regions has come from recent experiments in which these regions have been deleted, replaced, or transferred, resulting in substantial changes in the decay rates of individual mRNAs $(22,42,53,64,74,76)$. The most well-characterized of the UT elements are the 3' AU-rich sequences associated with the GM-CSF mRNA (and other lymphokine and protooncogene mRNAs $[12,50,74])$ and the $3^{\prime}$ stem-loop structure associated with the replication-dependent histone mRNAs $(21,68)$. Both the AU-rich sequence of GM-CSF mRNA and the stem-loop structure of histone mRNAs confer instability on their respective mRNAs, suggesting that they may be recognition or cleavage sites (or both) for specific nucleases.

Two additional factors, the extent of mRNA involvement in protein synthesis and the subcellular localization of mRNA, have been postulated to be important determinants of mRNA stability. The possibility that subcellular localization may affect mRNA decay rates is suggested by recent experiments with histone gene fusions which demonstrate that a relocalization of histone $\mathrm{H} 3$ mRNA to membranebound polysomes will simultaneously render that mRNA insensitive to the normal destabilization which accompanies

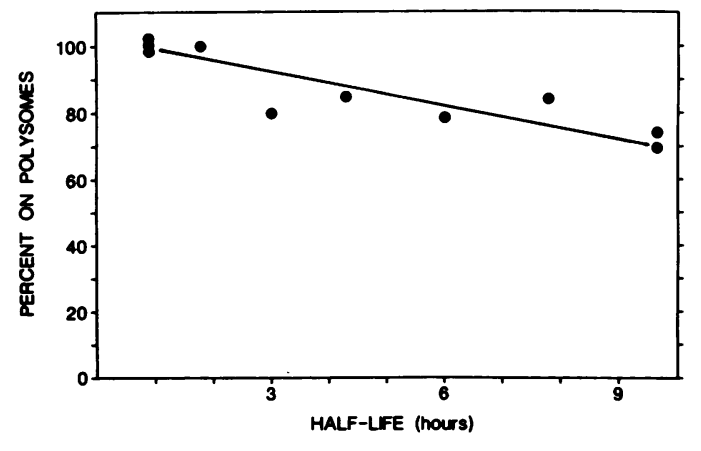

FIG. 11. Percentage of mRNA on polysomes as a function of mRNA half-life. For mRNAs of $>0.5 \mathrm{~kb}$ in length, the percentage of mRNA in polysomes (including monosomes) is plotted as a function of corrected mRNA half-life (Table 1). The percentage of mRNA in polysomes is taken as the sum of the values for fractions 1 to 8 in the data in Fig. 9. The line drawn through the data points is a least-squares best fit $(r=0.89)$.

the inhibition of DNA synthesis (88). A role for translational efficiency in the regulation of mRNA stability is suggested by the destabilizing effects of drugs which disrupt mRNAribosome association $(1,33)$, premature translational termination codons $(41,45)$, and clustered rare codons $(26)$. For all three types of effects it has been postulated that, when ribosome association is diminished or eliminated, mRNA degradation is enhanced by the increased access of specific nucleases to the mRNA. If this were to be a general rule, then it would be expected that stable mRNAs would be found in larger polysomes than unstable mRNAs of comparable size and stable mRNAs should be recruited into polysomes to a greater extent than unstable mRNAs. The data of Fig. 9 to 12 do not meet either of these expectations; we therefore conclude that the translational efficiency of an mRNA does not influence its decay rate in $D$. discoideum. This conclusion is supported by our recent experiments which indicate that the entire set of $D$. discoideum ribosomal protein mRNAs can exist in the cytoplasm of early developing cells in a stable, but untranslated, form (83). A lack of a relationship between mRNA stability and translatability has also been observed in other experimental systems $(38,71)$. To reconcile these conclusions with the destabilizing effects listed above, we note that all three types of effect lead to aberrant dissociation of mRNA from ribosomes. It is possible that such aberrant dissociation alters the normal interaction of mRNA with its standard complement of proteins (i.e., mRNP proteins), which, in turn, may make the mRNA more accessible to nucleases.

Our comparisons of the translational efficiencies of stable and unstable mRNAs indicated a correlation between the steady-state percentage of a given mRNA that was found in polysomes and the degree of instability of that mRNA (Fig. 11). Unstable mRNAs were more efficiently recruited into polysomes, although their average polysome size (per unit length of mRNA) did not differ significantly from that of stable mRNAs (Fig. 10). This suggests that their translational advantage may be limited to the binding of the first ribosome, an event which we postulate may be distinct from interactions with subsequent ribosomes. Since stable mRNAs are, on average, "older" mRNAs than unstable mRNAs, their disadvantage may be attributable to a timedependent modification. We have previously noted a timedependent shortening of mRNA poly $(A)$ tails $(58-60)$ as well as poly(A) length-dependent effects on mRNA translation 

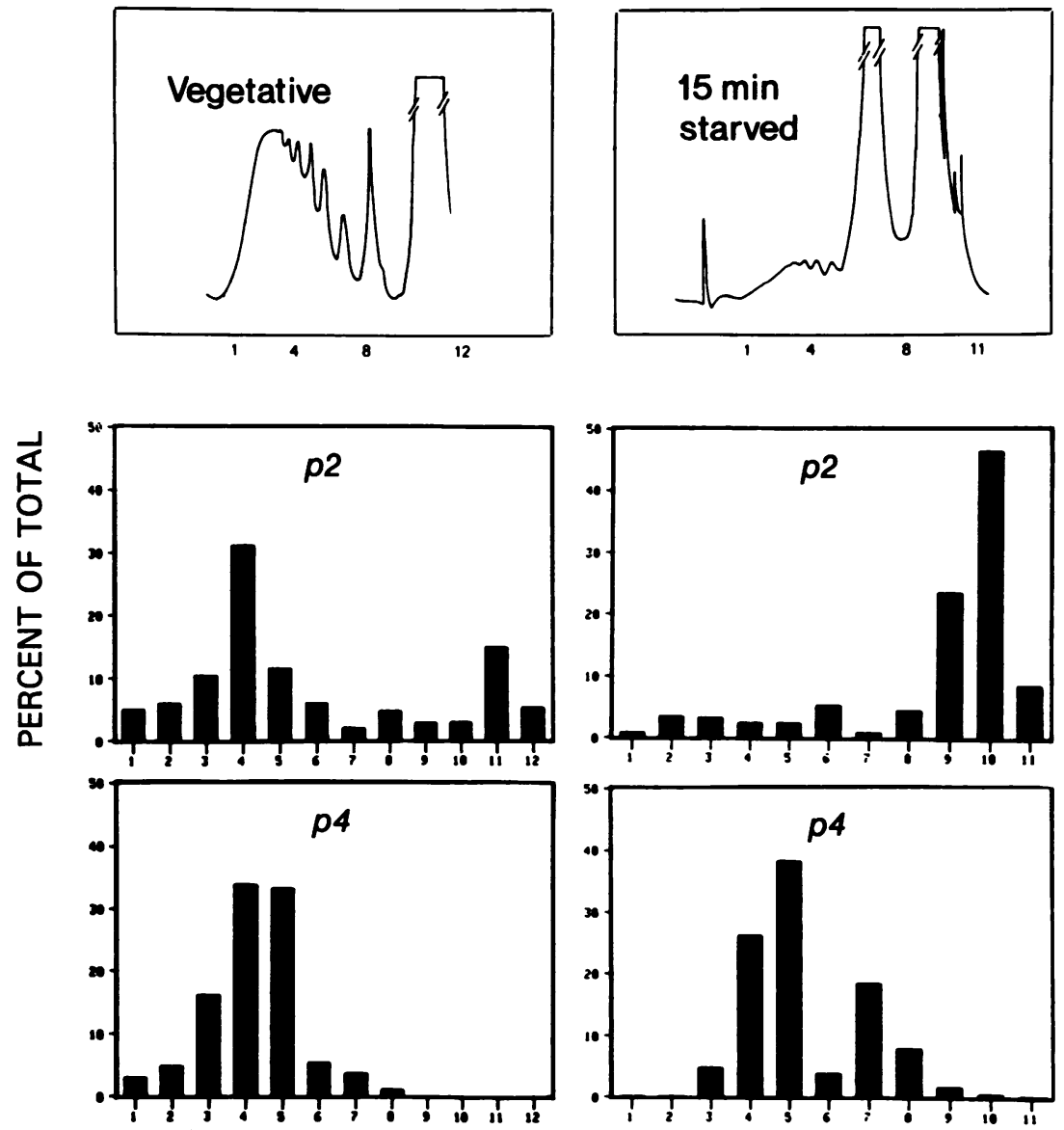

\section{FRACTION NUMBER}

FIG. 12. Polysome distribution of stable and unstable mRNAs in growing and developing cells. The polysomal distribution of the p2 (stable) and p4 (unstable) mRNAs are compared in growing and early developing cells. To initiate development, cells were harvested from growth medium, washed, and suspended in LPS buffer for $15 \mathrm{~min}$ (Shapiro, Ph.D. thesis). Polysomes from growing and developing cells were prepared and analyzed as in the legend to Fig. 9. (Left-hand panels [from Fig. 9]). Absorbance profile of polysomes and distributions of p2 and p4 mRNAs in vegetative cells. (Right-hand panels) Absorbance profile of polysomes and distributions of p2 and p4 mRNAs in cells developing (starving) for $15 \mathrm{~min}$.

$(31,61)$. We suggest that the observed ribosome recruitment differences between stable and unstable mRNAs may, in part, be explained by our postulated translational role for $\operatorname{poly}(A)(31,61)$.

The major objectives of this study were (i) the identification of mRNAs which differ significantly in their relative decay rates and (ii) a comparison of the sizes, poly $(\mathrm{A})$ tail lengths, and extents of ribosome loading of this set of mRNAs. Our analyses indicate that the decay rates of individual mRNAs can differ by at least 10 -fold and that such differences cannot be explained by differences in target size or protection of mRNA by ribosomes or poly $(A)$ tails. We conclude that random nucleolytic events do not play a significant role in the determination of mRNA decay rates.

\section{ACKNOWLEDGMENTS}

This work was supported by a Public Health Service grant to A.J. from the National Institutes of Health.

We thank Richard Firtel and David Ratner for providing some of the plasmids used in this study, Susan Longwell and Linda Dill for word processing assistance, and Laura Steel for critically evaluating the manuscript.

\section{LITERATURE CITED}

1. Allende, C. C., J. E. Allende, and R. A. Firtel. 1974. The degradation of ribonucleic acids injected into Xenopus laevis oocytes. Cell 2:189-196.

2. Alwine, J. C., D. J. Kemp, B. A. Parker, J. Reiser, J. Renart, G. R. Stark, and G. M. Wahl. 1979. Detection of specific RNAs or specific fragments of DNA by fractionation in gels and transfer to diazabenzyloxymethyl paper. Methods Enzymol. 68: 220-242.

3. Baker, E. J., L. R. Keller, J. A. Schloss, and J. L. Rosenbaum. 1986. Protein synthesis is required for rapid degradation of tubulin mRNA and other deflagellation-induced RNAs in Chlamydomonas reinhardi. Mol. Cell. Biol. 6:54-61.

4. Bender, W., N. Davidson, K. L. Kindle, W. C. Taylor, M. Silverman, and R. A. Firtel. 1978. The structure of M6, a recombinant plasmid containing Dictyostelium DNA homologous to actin messenger RNA. Cell 15:779-788.

5. Berger, S. L., and H. L. Cooper. 1975. Very short-lived and stable mRNAs from resting human lymphocytes. Proc. Natl. Acad. Sci. USA 72:3873-3877.

6. Birnboim, H. C., and J. Doly. 1979. A rapid alkaline extraction procedure for screening recombinant plasmid DNA. Nucleic Acids Res. 7:1513-1523.

7. Birnstiel, M. L., M. Busslinger, and K. Strub. 1985. Transcrip- 
tion termination and $3^{\prime}$ processing: the end is in site! Cell 41: 349-359.

8. Brawerman, G. 1981. The role of the poly(A) sequence in mammalian messenger RNA. Crit. Rev. Biochem. 10:1-38.

9. Brock, M. L., and D. J. Shapiro. 1983. Estrogen stabilizes vitellogenin mRNA against cytoplasmic degradation. Cell 34: 207-214.

10. Buell, G. N., M. P. Wickens, F. Payvar, and R. T. Schimke. 1978. Synthesis of full length cDNAs from four partially purified oviduct mRNAs. J. Biol. Chem. 253:2471-2482.

11. Cabrera, C. V., J. J. Lee, J. W. Ellison, R. J. Britten, and E. H. Davidson. 1984. Regulation of cytoplasmic mRNA prevalence in sea urchin embryos: rates of appearance and turnover for specific sequences. J. Mol. Biol. 174:85-111.

12. Caput, D., B. Beutler, K. Hartog, R. Thayer, S. Brown-Shimer, and $\mathbf{A}$. Cerami. 1986. Identification of a common nucleotide sequence in the $3^{\prime}$ untranslated region of mRNA molecules specifying inflammatory mediators. Proc. Natl. Acad. Sci. USA 83:1670-1674.

13. Carniero, M., and U. Schibler. 1984. Accumulation of rare and moderately abundant mRNAs in mouse L-cells is mainly posttranscriptionally regulated. J. Mol. Biol. 178:869-880.

14. Casey, L., C. M. Palatnik, and A. Jacobson. 1983. Messenger RNA half-life in Dictyostelium discoideum. Dev. Biol. 95:239243.

15. Chang, C. H., J. W. Yarbro, D. E. Mann, Jr., and R. F. Gautieri. 1978. Effects of 1,10-phenanthroline and a zinc complex of 1,10-phenanthroline on nucleic acid synthesis in mouse liver and spleen. J. Pharmacol. Exp. Ther. 205:27-32.

16. Deshpande, K. A., B. Chatterjee, and A. K. Roy. 1979. Translation and stability of rat liver messenger RNA for $\alpha_{2} \mu$-globulin in Xenopus oocytes. The role of terminal poly(A). J. Biol. Chem. 254:8937-8942.

17. Drummond, D. R., J. Armonstrong, and A. Colman. 1985. The effect of capping and polyadenylation on the stability, movement, and translation of synthetic messenger RNAs in Xenopus oocytes. Nucleic Acids Res. 13:7375-7394.

18. Ennis, H. L. 1981. Nogalomycin inhibits ribonucleic acid synthesis in growing and developing cells of the slime mold Dictyostelium discoideum. Antimicrob. Agents Chemother. 19:657665 .

19. Furuichi, Y., F. LaFinandra, and A. J. Shatkin. 1977. 5'Terminal structure and mRNA stability. Nature (London) 266: 235-239.

20. Gay, D. A., T. J. Yen, J. T. Y. Lau, and D. W. Cleveland. 1987. Sequences that confer $\beta$-tubulin autoregulation through modulated mRNA stability reside within exon 1 of a $\beta$-tubulin mRNA. Cell 50:671-679.

21. Geoghegan, T. E., and L. McCoy. 1986. Biogenesis and cell cycle relationship of poly(A) ${ }^{-}$actin mRNA in mouse ascites cells. Exp. Cell Res. 162:175-182.

22. Graves, R. A., N. B. Pandey, N. Chodchoy, and W. Marzluff. 1987. Translation is required for regulation of histone mRNA degradation. Cell 48:615-626.

23. Green, M. R., T. Maniatis, and D. A. Melton. 1983. Human $\beta$-globin pre-mRNA synthesized in vitro is accurately spliced in Xenopus oocyte nuclei. Cell 32:681-694.

24. Grunstein, M., and D. S. Hogness. 1975. Colony hybridization: a method for the isolation of cloned DNAs that contain a specific gene. Proc. Natl. Acad. Sci. USA 72:3961-3965.

25. Guyette, W. A., R. J. Matusik, and J. M. Rosen. 1979. Prolactinmediated transcriptional and post-transcriptional control of casein gene expression. Cell 17:1013-1023.

26. Hoekema, A., R. A. Kastelein, M. Vasser, and H. A. deBoer. 1987. Codon replacement in the PGK1 gene of Saccharomyces cerevisiae: experimental approach to study the role of biased codon usage in gene expression. Mol. Cell. Biol. 7:2914-2924.

27. Huez, G., Y. Cleuter, C. Bruck, L. Van Vloten-Doting, R. Goldbach, and B. Verduin. 1983. Translational stability of plant viral RNAs microinjected into living cells: influence of a 3'poly(A) segment. Eur. J. Biochem. 130:205-209.

28. Huez, G., G. Marbaix, D. Gallwitz, E. Weinberg, R. Devos, E. Hubert, and Y. Cleuter. 1978. Functional stabilization of HeLa cell histone messenger RNAs injected into Xenopus oocytes by 3'-OH polyadenylation. Nature (London) 271:572-573.

29. Huez, G., G. Marbaix, G. Hubert, M. Leclercq, U. Nudel, H. Soreq, R. Salomon, B. Lebleu, M. Revel, and U. Z. Littauer. 1974. Role of the polyadenylate segment in the translation of globin messenger RNA in Xenopus oocytes. Proc. Natl. Acad. Sci. USA 71:3143-3146.

30. Jacobson, A. 1976. Analysis of mRNA transcription in Dictyostelium discoideum or slime mold messenger RNA: how to find it and what to do with it once you've got it. Methods Mol. Biol. 8:161-209.

31. Jacobson, A., and M. Favreau. 1983. Possible involvement of poly(A) in protein synthesis. Nucleic Acids Res. 11:6353-6368.

32. Johnston, G. C., and R. A. Singer. 1978. RNA synthesis and control of cell division in the yeast $S$. cerevisiae. Cell 14:951958.

33. Kelly, R., D. R. Shaw, and H. L. Ennis. 1987. Role of protein synthesis in decay and accumulation of mRNA during spore germination in the cellular slime mold Dictyostelium discoideum. Mol. Cell. Biol. 7:799-805.

34. Kimmel, A. R., and R. A. Firtel. 1979. A family of short, interspersed repeat sequences at the 5' end of a set of Dictyostelium single-copy mRNAs. Cell 16:787-796.

35. Knecht, D. A., S. A. Cohen, W. F. Loomis, and H. F. Lodish. 1986. Developmental regulation of Dictyostelium discoideum actin gene fusions carried on low-copy and high-copy transformation vectors. Mol. Cell. Biol. 6:3973-3983.

36. Krieg, P. A., and D. A. Melton. 1984. Functional messenger RNAs are produced by SP6 in vitro transcription of cloned cDNAs. Nucleic Acids Res. 12:7057-7070.

37. Krishnamurti, C., L. A. Saryan, and D. H. Petering. 1980. Effects of ethylenediaminetetraacetic acid and 1,10-phenanthroline on cell proliferation and DNA synthesis of Erlich ascites cells. Cancer Res. 40:4092-4099.

38. Krowczynska, A., R. Yenofsky, and G. Brawerman. 1985. Regulation of messenger RNA stability in mouse erythroleukemia cells. J. Mol. Biol. 181:231-239.

39. Lengyel, J. A., and S. Penman. 1977. Differential stability of cytoplasmic RNA in a Drosophila cell line. Dev. Biol. 57:243253.

40. Lockhard, R. E., and C. D. Lane. 1978. Requirement for 7-methylguanosine in translation of globin mRNA in vivo. Nucleic Acids Res. 5:3237-3247.

41. Losson, R., and F. Lacroute. 1979. Interference of nonsense mutations with eucaryotic messenger RNA stability. Proc. Natl. Acad. Sci. USA 76:5134-5137.

42. Luscher, B., C. Stauber, R. Schindler, and D. Schumperli. 1985. Faithful cell-cycle regulation of a recombinant mouse histone $\mathrm{H} 4$ gene is controlled by sequences in the 3'-terminal part of the gene. Proc. Natl. Acad. Sci. USA 82:4389-4393.

43. Mangiarotti, G., P. Lefebvre, and H. F. Lodish. 1982. Differences in the stability of developmentally regulated mRNAs in aggregated and disaggregated Dictyostelium discoideum cells. Dev. Biol. 89:82-91.

44. Maniatis, T., E. F. Frisch, and J. Sambrook. 1982. Molecular cloning: a laboratory manual. Cold Spring Harbor Laboratory, Cold Spring Harbor, N.Y.

45. Maquat, L. E., A. J. Kinniburgh, E. A. Rachmilewitz, and J. Ross. 1981. Unstable B-globin mRNA in mRNA-deficient $\beta^{\circ}$ thalassemia. Cell 27:543-553.

46. Marbaix, G., G. Huez, A. Burny, Y. Cleuter, E. Hubert, M. Leclercq, H. Chantrenne, H. Soreq, U. Nudel, and U. Z. Littauer. 1975. Absence of polyadenylate segment in globin messenger RNA accelerates its degradation in Xenopus occytes. Proc. Natl. Acad. Sci. USA 72:3065-3067.

47. Margolskee, J. P., and H. F. Lodish. 1980. Half-lives of messenger RNA species during growth and differentiation of Dictyostelium discoideum. Dev. Biol. 74:37-49.

48. McCrae, M. A., and H. R. Woodland. 1981. Stability of nonpolyadenylated viral mRNAs injected into frog oocytes. Eur. J. Biochem. 116:467-470.

49. Mehdy, M. C., D. Ratner, and R. A. Firtel. 1983. Induction and modification of cell-type specific gene expression in Dictyoste- 
lium. Cell 32:763-771.

50. Meijlink, F., T. Curran, A. D. Miller, and I. M. Verma. 1985. Removal of a 67-base-pair sequence in the noncoding region of protooncogene fos converts it to a transforming gene. Proc. Natl. Acad. Sci. USA 82:4987-4991.

51. Mercer, J. F. B., and S. A. Wake. 1985. An analysis of the rate of poly(A)-shortening using RNA blot hybridization. Nucleic Acids Res. 13:7929-7942.

52. Meyuhas, O., and R. P. Perry. 1979. Relationship between size, stability and abundance of the messenger RNA of mouse L cells. Cell 16:139-148.

53. Morris, T., F. Marashi, L. Weber, E. Hickey, D. Greenspan, J. Bonner, J. Stein, and G. Stein. 1986. Involvement of the 5 -leader sequence in coupling the stability of a human $\mathrm{H} 3$ histone mRNA with DNA replication. Proc. Natl. Acad. Sci. USA 83:981-985.

54. Nilsson, G., J. G. Belasco, S. N. Cohen, and A. von Gabain. 1984. Growth-rate dependent regulation of mRNA stability in Escherichia coli. Nature (London) 312:75-77.

55. Nordstrom, J. L., D. R. Roop, M. J. Tsai, and B. W. O'Malley. 1979. Identification of potential ovomucoid mRNA precursors in chick oviduct nuclei. Nature (London) 278:328-331.

56. Nudel, U., H. Soreq, U. Z. Littauer, G. Marbaix, G. Huez, M. Leclerq, E. Hubert, and H. Chantrenne. 1976. Globin mRNA species containing poly(A) segments of different lengths. Their functional stability in Xenopus oocytes. Eur. J. Biochem. 64: $115-121$.

57. Ouellette, A. J., and R. A. Malt. 1976. Accumulation and decay of messenger ribonucleic acid in mouse kidney. Biochemistry 15:3358-3372.

58. Palatnik, C. M., R. V. Storti, A. K. Capone, and A. Jacobson. 1980. Messenger RNA stability in Dityostelium discoideum: does poly(A) have a regulatory role? J. Mol. Biol. 141:99-118.

59. Palatnik, C. M., R. V. Storti, and A. Jacobson. 1979. Fractionation and functional analysis of newly synthesized and decaying messenger RNAs from vegetative cells of Dictyostelium discoideum. J. Mol. Biol. 128:371-395.

60. Palatnik, C. M., R. V. Storti, and A. Jacobson. 1981. Partial purification of a developmentally regulated messenger RNA from Dictyostelium discoideum by thermal elution from poly(A)-Sepharose. J. Mol. Biol. 150:389-398.

61. Palatnik, C. M., C. Wilkins, and A. Jacobson. 1984. Translational control during early Dictyostelium development: possible involvement of poly(A) sequences. Cell 36:1017-1025.

62. Peacock, A. C., and C. W. Dingman. 1967. Molecular weight estimation and separation of ribonucleic acid by electrophoresis on agarose-acrylamide composite gels. Biochemistry 6:1818 1827.

63. Perry, R. P., and D. E. Kelley. 1973. Messenger RNA turnover in mouse $\mathrm{L}$ cells. J. Mol. Biol. 79:681-696.

64. Rabbitts, P. H., A. Forster, M. A. Stinson, and T. H. Rabbitts. 1985. Truncation of exon 1 from the c-myc gene results in prolonged c-myc mRNA stability. EMBO J. 4:3727-3733.

65. Rave, N., R. Crkvenjakov, and H. Boedtker. 1979. Identification of pro-collagen mRNAs transferred to diazobenzyloxylmethyl paper from formaldehyde agarose gels. Nucleic Acids Res. 6: 3559-3567.

66. Restifo, L. L., and G. M. Guild. 1986. Poly(A) shortening of coregulated transcripts in Drosophila. Dev. Biol. 115:507-510.

67. Romans, P., and R. A. Firtel. 1985. Organization of the Dictyostelium discoideum actin multigene family: flanking sequences show subfamily homologies and unusual dyad symmetries. J. Mol. Biol. 183:311-326.

68. Ross, J., S. W. Peltz, G. Kobs, and G. Brewer. 1986. Histone mRNA degradation in vivo: the first detectable step occurs at or near the $3^{\prime}$ terminus. Mol. Cell. Biol. 6:4362-4371.

69. Ross, J., and A. Pizarro. 1983. Human beta and delta globin messenger RNAs turn over at different rates. J. Mol. Biol. 167: 607-617.

70. Rowekamp, W., and R. A. Firtel. 1980. Isolation of develop- mentally regulated genes from Dictyostelium. Dev. Biol. 79: 409-418.

71. Santiago, T. C., A. J. E. Bettany, I. J. Purvis, and A. J. P. Brown. 1987. Messenger RNA stability in Saccharomyces cerevisiae: the influence of translation and $\operatorname{poly}(\mathrm{A})$ tail length. Nucleic Acids Res. 15:2417-2429.

72. Santiago, T. C., I. J. Purvis, A. J. E. Bettany, and A. J. P. Brown. 1986. The relationship between mRNA stability and length in Saccharomyces cerevisiae. Nucleic Acids Res. 14: $8347-8360$.

73. Sehgal, P. B., H. Soreq, and I. Tamm. 1978. Does $3^{\prime}$-terminal poly(A) stabilize human fibroblast interferon mRNA in oocytes of Xenopus laevis. Proc. Natl. Acad. Sci. USA 75:5030-5033.

74. Shaw, G., and R. Kamen. 1986. A conserved AU sequence from the $3^{\prime}$ untranslated region of GM-CSF mRNA mediates selective mRNA degradation. Cell 46:659-667.

75. Sheiness, D., and J. E. Darnell. 1973. Polyadenylic acid segment in mRNA becomes shorter with age. Nature (London) New Biol. 241:265-268.

76. Simcox, A. A., C. M. Cheney, E. P. Hoffman, and A. Shearn. 1985. A deletion of the $3^{\prime}$ end of the Drosophila melanogaster hsp70 gene increases stability of mutant mRNA during recovery from heat shock. Mol. Cell. Biol. 5:3397-3402.

77. Singer, R. H., and G. Kessler-Icekson. 1978. Stability of polyadenylated RNA in differentiating myogenic cells. Eur. J. Biochem. 88:395-402.

78. Singer, R. H., and S. Penman. 1973. Messenger RNA in HeLa cells: kinetics of formation and decay. J. Mol. Biol. 78:321-334.

79. Sive, H. L., N. Heintz, and R. G. Roeder. 1984. Regulation of human histone gene expression during the HeLa cell cycle requires protein synthesis. Mol. Cell. Biol. 4:2723-2734.

80. Southern, E. 1975. Detection of specific sequences among DNA fragments separated by gel electrophoresis. J. Mol. Biol. 98: 503-517.

81. Spradling, A., H. Hui, and S. Penman. 1975. Two very different components of messenger RNA in an insect cell line. Cell 4:131137.

82. Steel, L. F., and A. Jacobson. 1986. Ribosomal proteins are encoded by single copy genes in Dictyostelium discoideum. Gene 41:165-172.

83. Steel, L. F., and A. Jacobson. 1987. Translational control of ribosomal protein synthesis during early Dictyostelium discoideum development. Mol. Cell. Biol. 7:965-972.

84. Swartwout, S. G., H. Preisler, W. Guan, and A. J. Kinniburgh. 1987. Relatively stable population of c-myc RNA that lacks long poly(A). Mol. Cell. Biol. 7:2052-2058.

85. Vieira, J., and J. Messing. 1982. A new pair of M13 vectors for selecting either DNA strand of double-digest restriction fragments. Gene 19:269-276.

86. Volloch, V., and D. Housman. 1981. Regulation of stability of non-globin mRNA in Friend cells, p. 259-266. In G. Stamatoyannopoulous and A. W. Nienhuis (ed.), Organization and expression of globin genes. Alan R. Liss, Inc., New York.

87. Wickens, M. P., G. N. Buell, and R. T. Schimke. 1978. Synthesis of double-stranded DNA complementary to lysozyme, ovomucoid, and ovalbumin mRNAs. J. Biol. Chem. 253:2483-2495.

88. Zambetti, G., J. Stein, and G. Stein. 1987. Targeting of a chimeric human histone fusion mRNA to membrane-bound polysomes in HeLa cells. Proc. Natl. Acad. Sci. USA 84:26832687.

89. Zaret, K. S., and F. Sherman. 1984. Mutationally altered $3^{\prime}$ ends of yeast cycl mRNA affect transcript stability and translational efficiency. J. Mol. Biol. 176:107-135.

90. Zeevi, M., J. R. Nevins, and J. E. Darnell. 1982. Newly formed mRNA lacking polyadenylic acid enters the cytoplasm and the polyribosomes but has a shorter half-life in the absence of polyadenylic acid. Mol. Cell. Biol. 2:517-525.

91. Zuker, C., and H. F. Lodish. 1981. Repetitive DNA sequences cotranscribed with developmentally regulated Dictyostelium discoideum mRNAs. Proc. Natl. Acad. Sci. USA 78:5386-5390. 